\title{
ANTIREFLUX URETEROILEAL ANASTOMOSIS FOR ORTHOTOPIC ILEAL NEOBLADDER USING WALLACE TECHNIQUE IN A SINGLE TROUGH
}

\author{
Hany Mostafa Abdullah, Karim Omar Nassar, Hossam Mohamed El Awady and \\ Sherif Osama Abdel Fattah*
}

\begin{tabular}{l}
\hline \\
Department of Urology, \\
Faculty of Medicine, Ain \\
Shams University, Ain Shams \\
University, Cairo, Egypt. \\
Corresponding : \\
Sherif Osama Abdel Fattah \\
Mobile: 01069078238 \\
E mail: \\
sherifosama@med.asu.edu.eg \\
Received: $24 / 10 / 2019$ \\
Accepted: 20/11/201
\end{tabular}

Department of Urology, Faculty of Medicine, Ain Shams University, Ain Shams University, Cairo, Egypt Corresponding :

Sherif Osama Abdel Fattah Mobile: 01069078238 sherifosama@med.asu.edu.eg Accepted: 20/11/201

\begin{abstract}
Background: The creation of antireflux mechanism for ureteroileal anastomosis in a low- pressure pouch is controversial and benefits should be weighted by possible morbidity. Different techniques were used as antireflux to preserve the upper urinary tract.

Aim of the Work: to evaluate a modification of the subserous extramural tunnel for non-refluxing uretero-ileal anastomosis in orthotopic diversion using Wallace technique in a single trough after 2-year-duration follow up in terms of uretero-ileal anastmosis stricture, reflux and urinary tract infections.
\end{abstract}

Patients and Methods: In all, 100 patients underwent orthotopic urinary diversion after radical cystectomy. Inclusion criteria included age from 30 to 65 years old, negative positive urethral margin, serum creatinine less than $2 \mathrm{mg} / \mathrm{dl}$ and tumor stage T2-T3. Exclusion criteria were stricture urethra, single kidney and poor performance status. Patients were followed up by serum creatinine, pouchogram, renal ultrasound and intravenous pyelogram if serum creatinine below $1.5 \mathrm{mg} / \mathrm{dl}$.

Results: In all, 2 patients missed follow up and 98 patients were evaluable over 24 months. Mean serum creatinine raised from 1.16 preoperative to 1.20 after 2 years. Reflux has been detected in 3 patients while stricture has affected 3 patients. 9 patients had symptomatic urinary tract infections or being infected with organism other than E.coli that necessitated admission and parenteral antibiotics; three of which were advised to do clean intermittent catheterization.

Conclusion: Combining serous-lined extramural tunnel and Wallace techniques is an effective technique and has a comparable result to the other antirefluxing techniques in terms of ureteroileal stricture, reflux and acute pyelonephritis.

Keywords: Radical Cystectomy, Urinary Diversion, Antireflux, Single Trough.

\section{INTRODUCTION}

The creation of antireflux mechanism for ureteroileal anastomosis in a lowpressure pouch is controversial and benefits should be weighted by possible morbidity. The ideal technique should be technically simple without synthetic materials or very lengthy segment of intestine. ${ }^{(1)}$ 
Split-cuff technique, Le Duc sulcus, submucosal tunneling and Kock procedure are associated with ureteric obstruction with subsequent upper tract dilatation. This incidence is $3-5.3 \%$ in hemi-Kock pouch. Moreover, studies on Le Duc mucosal sulcus revealed widely varied results regarding stricture and reflux rates and this variation was attributed to irregular creeping of intestinal mucosa over the embedded ureters $^{(2)}$

In 2001, Abol-Enein et al. conducted a study on complications of the subserous lined extramural tunnel for ureteroileal anastomosis. Pouch was W-shaped, and each ureter has its own tunnel. Authors reported a rate of stricture related renal affection of $3.8 \%{ }^{(3)}$

\section{THE AIM OF THE WORK:}

The aim of our study is to follow up results of a technique that combines the subserous lined extramural tunneled with Wallace technique in U- shaped pouch ${ }^{(4)}$.

\section{PATIENTS AND METHODS}

Between July 2017 and July 2019, 100 patients were followed up after being undergone a new antireflux technique after cystectomy. Cases were operated in Urology Department at Ain Shams University Hospital after being consented. Inclusion criteria were; age from 30 to 65 years old, negative positive urethral margin, serum creatinine less than $2 \mathrm{mg} / \mathrm{dl}$ and tumor stage T2-T3. Exclusion criteria were stricture urethra, single kidney and poor performance status. This technique included creation of a subserous extramural tunnel, in between both limbs of the chosen ileal segment, for ureteroileal anastomosis. Both ureters were implanted by the Wallace technique.

Follow up regimen included; assessment of medical history (especially for chills, rigors and loin pain), clinical examination (especially temperature and for loin tenderness), laboratory investigations (complete blood count, serum creatinine, serum electrolytes; Sodium and Potassium and urine culture) every month in the $1^{\text {st }}$ year postoperative then every 3 months in the $2^{\text {nd }}$ year. On the $1^{\text {st }}$ month postoperative, every patient undergone pouchogram. On the $6^{\text {th }}$ month postoperative, every patient undergone pelviabdominal ultrasound "PAUS", intravenous pyelogram "IVP" and pouchogram. On $12^{\text {th }}$ month postoperative, every patient undergone pelviabdominal ultrasound "PAUS", intravenous pyelogram "IVP" and pouchogram. On the $24^{\text {th }}$ month postoperative, every patient undergone pelviabdominal ultrasound "PAUS", intravenous pyelogram "IVP" and pouchogram. Follow up took place in the urology outpatient clinic at Ain Shams University Hospital. 98 patients completed the follow up regimen and were evaluable after 2 years of follow up.

\section{Statistical methodology:}

Data were analyzed on statistical package for social science (SPSS) version 21 for windows (IBM corp, Armonk, NY, USA). Quantitative data were expressed Mean, and standard deviation ( \pm SD), or Median, Minimum and maximum for parametric and non-parametric data respectively. Categorical data were expressed as numbers and percentages. Comparison between quantitative data was done using student $t$ test ( $\mathrm{t}$ ) and MannWhitney test depending on data distribution and number of groups involved in the comparison. 


\section{RESULTS}

Table (1): Distribution of age and gender of studied patients

\begin{tabular}{|c|c|c|}
\hline \multicolumn{2}{|c|}{} & No. (\%) \\
\hline \multirow{2}{*}{ Gender } & Females & $2(2.04 \%)$ \\
\cline { 2 - 3 } & Males & $96(97.95 \%)$ \\
\hline \multirow{2}{*}{ Age } & Mean \pm SD & $55.81 \pm 6.49$ \\
\cline { 2 - 3 } & Range & $40-65$ \\
\hline
\end{tabular}

After 1 year, one case of anastomotic total of 2 cases $(2.04 \%)$ after two years stricture was diagnosed $(1.02 \%)$ with follow up. another case diagnosed on the $2^{\text {nd }}$ year with Table (2): Distribution of anastomotic stricture after 1 year and after 2 years of operation

\begin{tabular}{|c|c|c|c|c|c|c|}
\hline \multicolumn{2}{|c|}{} & At 1 year & At 2 years & \multicolumn{3}{c|}{ Chi-square test } \\
\cline { 3 - 8 } & No. (\%) & No. $(\%)$ & $\mathrm{X}^{2}$ & P-value & Sig. \\
\hline \multirow{2}{*}{ Stricture (IVP) } & No & $97(98.9 \%)$ & $96(97.9 \%)$ & & & \\
\cline { 2 - 5 } & Yes & $1(1.02 \%)$ & $2(2.04 \%)$ & 0.339 & 0.560 & NS \\
\hline
\end{tabular}

In 98 patients, vesicoureteral reflux $(2.0 \%)$ in the first 1 year then 1 case was (VUR) was detected in only two patients detected in the second year of follow up.

Table (3): Distribution of reflux after 6 months and after one year

\begin{tabular}{|c|c|c|c|c|c|c|}
\hline \multicolumn{2}{|c|}{} & At 1 year & At 2 years & \multicolumn{3}{c|}{ Chi-square test } \\
\cline { 3 - 7 } \multicolumn{2}{|c|}{} & No. (\%) & No. (\%) & $X^{2}$ & P-value & Sig. \\
\hline \multirow{3}{*}{ Reflux } & No & $96(97.9 \%)$ & $95(96.9 \%)$ & & & \\
\cline { 2 - 6 } & Yes & $2(2.04 \%)$ & $3(3.06 \%)$ & 0.339 & 0.560 & NS \\
\hline
\end{tabular}

In all patients, 5 cases $(5.1 \%)$ suffered $(2.04 \%)$ suffered pyelonephritis in the $2^{\text {nd }}$ pyelonephritis in the $1^{\text {st }}$ year and 2 cases year.

Table (4): Distribution of occurrence of pyelonephritis among studied patients

\begin{tabular}{|c|c|c|c|c|c|}
\hline \multirow{2}{*}{} & At 1 year & At 2 years & \multicolumn{3}{|c|}{ Chi-square test } \\
\cline { 2 - 6 } & No. (\%) & No. $(\%)$ & $\mathrm{X}^{2}$ & P-value & Sig. \\
\hline Pyelonephritis & $5(5.10 \%)$ & $2(2.04 \%)$ & 3.067 & 0.547 & NS \\
\hline
\end{tabular}

The mean serum creatinine level of the postoperatively, this difference was patients before the operation was $1.16 \mathrm{mg} / \mathrm{dl} \quad$ statistically insignificant $(\mathrm{P}=0.488)$. which increased to $1.20 \mathrm{mg} / \mathrm{dl}$ Table (5): Comparison between the mean creatinine level before and after operation

\begin{tabular}{|c|c|c|c|c|c|c|}
\hline \multirow{2}{*}{ S. Creatinine } & Preoperative & At 1 year & At 2 years & Paired t-test & P-value & Sig. \\
\cline { 2 - 4 } & No. $=100$ & No. $=98$ & No. $=98$ & & & \\
\hline Mean \pm SD & $1.16 \pm 0.34$ & $1.20 \pm 0.50$ & $1.20 \pm 0.32$ & $0.571^{*}$ & 0.488 & NS \\
\hline Range & $0.6-1.7$ & $0.6-2.1$ & $0.5-2.0$ & & & \\
\hline
\end{tabular}

\section{DISCUSSION:}

Antireflux ureteroileal anastomosis has been created to protect against ascending infections to upper urinary tract and to avoid recurrent attacks of pyelonephritis with subsequent damage to renal tissue ${ }^{(3)}$.
Different studies were conducted to create safe and effective antireflux techniques especially in terms of low stricture rate and preserving the upper urinary tract. Abol-Enein et al. in 1994, described a technique entailing creation 2 extramural serous-lined tunnels in a Wshaped ileal segment for ureteroileal 
implantation and it proved its efficiency with comparable results to the refluxing anastomosis ${ }^{(5)}$.

Shigemura et al. compared Wallace direct ureteroileal anastomosis with the LeDuc antireflux procedure in 72 patients after creation of modified Studer orthotopic neobladder. Reflux was reported in 6 renal units $(9.6 \%)$ in the Le Duc group and in 29 renal units (38.2\%) in the Wallace technique group $^{(6)}$.

El Fayoumy et al. followed up a new technique in ureteroileal anastomosis on 12 patients. It included use of the flat-segment technique. After following up for 6-18 months, they reported eleven patients had no reflux $(92 \%)$. However, one patient had bilateral reflux ${ }^{(7)}$.

Hassan et al. compared the direct refluxing Nesbit technique in 58 patients and the antirefluxing Le Duc technique in 62 patients. In the Le Duc group, four patients $(6.5 \%)$ had a reflux. While in the Nesbit technique group, no patient had ureteroileal stricture ${ }^{(8)}$.

After a minimum follow up of 51 cases for 20 months, technique of AbolEnein et al. showed there were no reflux ${ }^{(9)}$.

In 2001, Abol-Enein and Ghoneim conducted a huge study that revealed results of 344 patients who underwent radical cystectomy and orthotopic urinary diversion using serous-lined extramural technique for ureteroileal anastomosis. They concluded that reflux rate was $3 \%^{(4)}$.

Our study followed up 98 patients over 2 years and revealed a ureteroileal reflux in 3 patients $(3.06 \%)$ over 2 years but the rate was decreasing over months; 2 patients in the 1st year and declined to 1 patient in the 2nd year. ElFayoumy et al., after following up for 6-18 months, they reported no cases of ureteroileal obstruction ${ }^{(7)}$.

Hassan et al. revealed the following results; in the Le Duc group, six patients
(9.6\%) had a unilateral ureteroileal stricture while in the Nesbit technique group, no patient had ureteroileal stricture ${ }^{(8)}$.

Abol-Enein et al. showed ureteroileal stricture in 3 renal units which needed surgical intervention after failure of endoscopic intervention ${ }^{(9)}$.

In 2011, Abol-Enein and Ghoneim, ureteroileal stricture rate was $4 \%{ }^{(4)}$.

Harraz et al. conducted a study that compared results of serous-lined extramural ureteroileal implantation and direct anastomosis over a period from 1 to 10 years. It revealed ureteroileal stricture in 5 renal units in the 1st-year follow up; 3 of them were improved by endoscopic intervention, while the other 2 needed surgical intervention ${ }^{(10)}$.

Our study followed up 98 patients over 2 years and revealed stricture in 3 patients $(3.06 \%)$, one of them was at level of the upper ureter and it was probably due to excessive ureteric dissection with affection of the blood supply. Two patients were managed by endoscopic intervention while one patient was treated by antegrade double $\mathrm{J}$ then it needed surgical intervention later.

Harraz et al. reported affection of 4 patients with acute pyelonephritis ${ }^{(10)}$.

Shigemura et al. reported pyelonephritis in $6.7 \%$ of patients in the Le Duc group and $3.4 \%$ of patients in the Wallace direct anastomosis group ${ }^{(6)}$.

In our study, acute pyelonephritis affected 5 patients over the first year, one of them had an upper ureteric stricture and infection was improved by nephrostomy and antibiotics. Over the 2nd year, 2 patients were affected by acute pyelonephritis. They were admitted and received antibiotic therapy according to the culture results.

Hassan et al. recorded that the mean serum creatinine before the operation in the Nesbit technique group was $1.1 \mathrm{mg} / \mathrm{dL}$ and 
in the Le Duc technique group was $1 \mathrm{mg} / \mathrm{dL}^{(8)}$.

In our study, the mean serum creatinine level of the patients before the operation was $1.16 \mathrm{mg} / \mathrm{dl}$ which increased to $1.2 \mathrm{mg} / \mathrm{dl} 12$ months postoperatively and it remains constant after 2 years of follow up.

Our technique has the advantage of the serous lining of the extramural tunnel that facilitates the healing of ureteroileal anastomosis. This was combined by Wallace technique which facilitated any endoscopic intervention for complications as the surgeon was able to gauge the 2 orifices at the posterior wall of the pouch. On the other hand, limitations of our study include; difficulty in imagination of the configuration of the single trough in addition to the need for longer time and more patients for following up and to justify the role of our technique.

\section{Conclusion:}

Combining serous-lined extramural tunnel and Wallace techniques is an effective technique and has a comparable result to the other antirefluxing techniques in terms of ureteroileal stricture, reflux and acute pyelonephritis.

\section{REFERENCES}

1. Stein R, Hohenfellner M, Pahernik S, Roth $S$, Thüroff JW, Rübben H (2019): Urinary Diversion. Dtsch Aerzteblatt Online; 109 (38): 617-22.

2. Ghoneim MA, Osman Y (2007): Ureterointestinal anastomosis in low-pressure reservoirs: refluxing or antirefluxing? BJU Int.; 100(6): 1229-33.

3. Singh UP, Jena R, Madhavan K, Kumar N, Sureka SK, Srivastava A (2019): Radical cystectomy and $\mathrm{W}$-shaped ileal orthotopic neobladder reconstruction with serosa-lined tunneled ureteroileal anastomoses: A critical analysis of the short-term voiding patterns and urodynamic and functional outcomes. Indian J Urol; 35(2): 121-8.

4. Abol-enein H, Ghoneim MA (2001): Functional Results Of Orthotopic Ileal Neobladder With Serous-Lined Extramural Ureteral Reimplantation: Experience With 450 Patients; 165:1427-32.

5. Abol-Enein H, Ghoneim MA (1994): A novel uretero-ileal reimplantation technique: The serous lined extramural tunnel. A preliminary report. J Urol.; 151(5): 1193-7.

6. Shigemura $\mathrm{K}$, Yamanaka N, Imanishi $\mathrm{O}$, Yamashita M (2012): Wallace direct versus anti-reflux Le Duc ureteroileal anastomosis: Comparative analysis in modified Studer orthotopic neobladder reconstruction. Int $\mathrm{J}$ Urol; 19(1): 49-53.

7. Elfayoumy $\mathrm{H}$, Abou-Elela $\mathrm{A}$, Orban $\mathrm{T}$, Emran A, Elghoneimy M, Morsy A (2011): A novel antireflux technique for orthotopic ileal bladder substitutes-flat-segment technique: preliminary results. ISRN Urol; 2011: 431951.

8. Hassan AA, Elgamal SA, Sabaa MA, Salem KA, Elmateet MS (2007): Evaluation of direct versus non-refluxing technique and functional results in orthotopic Y-ileal neobladder after 12 years of follow up. Int J Urol; 14(4): 300-4.

9. Ghoneim MA (1995): Further clinical experience with the ileal $\mathrm{W}$ - neobladder and a serous-lined extramural tunnel for orthotopic substitution; 558-64.

10. Harraz AM, Mosbah A, Abdel-latif M, Elassmy A, Gad H, Shaaban AA (2014): Impact of the type of ureteroileal anastomosis on renal function measured by diuretic scintigraphy : long-term results of a prospective randomized study.; 202-9. 
استخدام التفاغم الحالبي اللفائفي ضد الارتجاع البولي بمثانة اللفائفي المخلقة سوية الوضع باستخدام

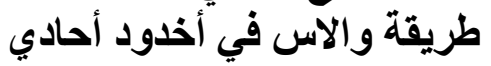

هاني مصطفى عبد الله، كريم عمر نصار، حسام محمد العوضي وشريف أسامه عبد الفتاح

قسم جر احة المسالك البولية ـ كلية الطب - جامعة عين شمس علمس

الخلفية: تستخدم الامعاء في اعادة بناء الجهاز البولي السفلي وتعتبر الصورة الثثالية من صور مخزنات البول البكان

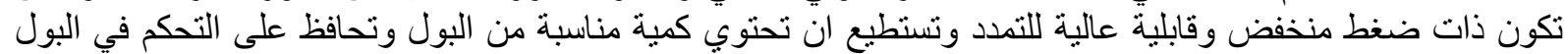

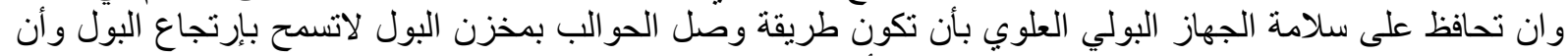

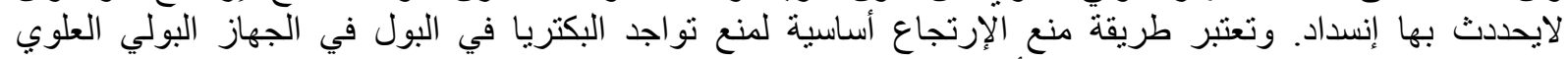

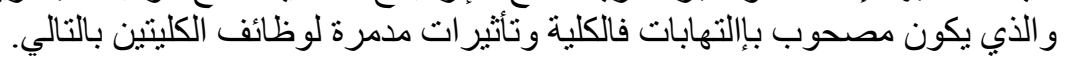

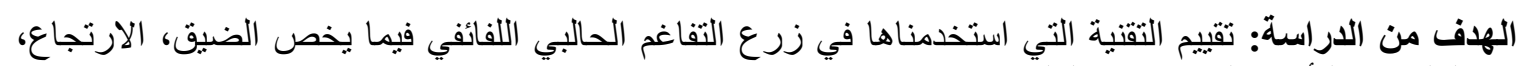

إلتهابات الكليتين و الثأثير على وظائف الكلى.

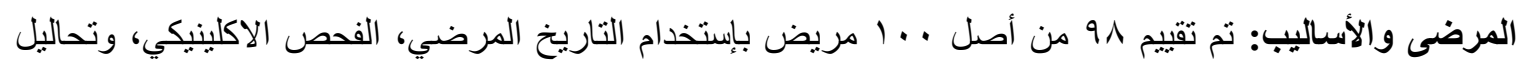

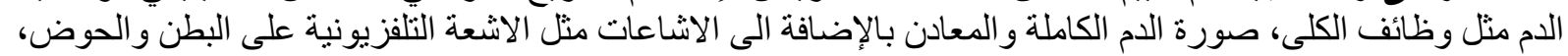

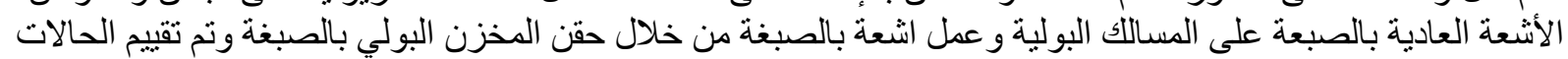
على مدار سنتين.

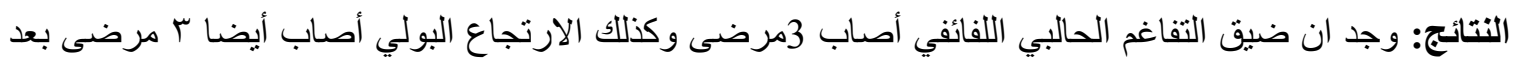

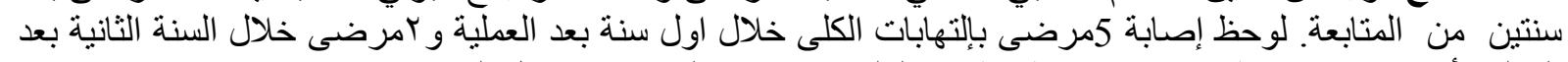

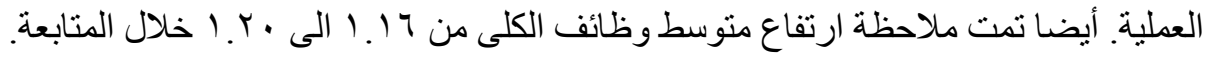

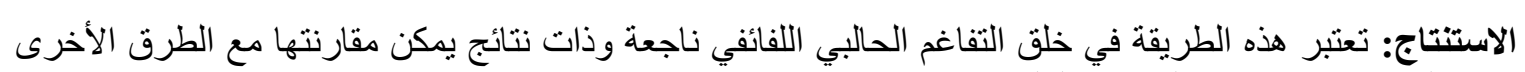
فيما يخص الضيق، الارتجاع و إلتهابات الكلية. 